\title{
Correction to: Archaeology at First Government House, Sydney
}

\section{Correction to:}

\author{
Chapter 5 in: T. Murray, P. Crook, Exploring the Archaeology \\ of the Modern City in Nineteenth-century Australia, \\ Contributions To Global Historical Archaeology, \\ https://doi.org/10.1007/978-3-030-27169-5_5
}

The book was inadvertently published with an incorrect figure legends for figures 5.7 as "One of the two black basalt sherds recovered from the site (YRP6211). This was probably the base of a tea-serving vessel, probably a teapot or sugar basin. It was recovered from a thick layer of yellow clay above a barrel drain, near the guard house and predates 1810" and 5.8 as "Oval sauce tureen in creamware, impressed '3' (YRP6089)" where as it should be

\section{7 "Oval sauce tureen in creamware, impressed '3' (YRP6089)”}

5.8" One of the two black basalt sherds recovered from the site (YRP6211). This was probably the base of a tea-serving vessel, probably a teapot or sugar basin. It was recovered from a thick layer of yellow clay above a barrel drain, near the guard house and predates 1810".

These lengends has been corrected in the book.

The updated online version of this chapter can be found at https://doi.org/10.1007/978-3-030-27169-5_5 